Article

\title{
Evidence of Gas Hydrates in Block 26-Offshore Trinidad
}

\author{
Jill Marcelle-De Silva ${ }^{1, *}$, Adrian Thomas ${ }^{2, \dagger}$, Wanda Lee De Landro Clarke ${ }^{3}$ and \\ Michelle Allum ${ }^{4}$
}

1 Petroleum Studies Unit, Department of Chemical Engineering, The University of the West Indies, St. Augustine Campus, St. Augustine, Trinidad and Tobago

2 St. Mary's College, Fenham Hall Drive, Flat E, Newcastle upon Tyne, NE4 9YH, UK;

E-Mail: a.k.thomas@newcastle.ac.uk

3 Ministry of Energy and Energy Industries, Level 23, Tower C, International Waterfront Centre, \#1 Wrightson Road, Port of Spain, Trinidad and Tobago; E-Mail: wclarke@energy.gov.tt

4

PetroCom Technologies Limited, 80 Woodford Street, Newtown, Port of Spain,

Trinidad and Tobago; E-Mail: michelle.allum@petrocomtech.com

$\dagger$ Study conducted at PetroCom Technologies Limited, 80 Woodford Street, Newtown, Port of Spain, Trinidad and Tobago.

* Author to whom correspondence should be addressed; E-Mail: jill.marcelle-desilva@sta.uwi.edu; Tel.: +1-868-662-2002 (ext. 83284); Fax: +1-868-662-4414.

Received: 15 March 2012; in revised form: 26 March 2012 / Accepted: 22 April 2012 /

Published: 3 May 2012

\begin{abstract}
Natural gas hydrates are increasingly viewed as a potential economic resource as energy demands rise. In this study, three-dimensional seismic data for Block 26 in the Atlantic Continental Margin offshore Trinidad were evaluated to determine if there is the potential for oceanic hydrate-bearing sediments. The seismic dataset covered an area of approximately $1210 \mathrm{~km}^{2}$ of the continental slope. A bottom simulating reflector which generally ran parallel to the sea floor and cut the dominant stratigraphy was observed and mapped over approximately $43 \%$ of the study area.
\end{abstract}

Keywords: hydrates; Trinidad; unconventional reservoir 


\section{Introduction}

As global energy demands rise, it becomes increasingly critical to identify unconventional sources of hydrocarbons. One alternative is natural gas hydrates. These are ice-like crystalline substances, composed of gas and water molecules that exist at relatively high pressures ( $>30$ bar) and low temperatures $\left(<20^{\circ} \mathrm{C}\right)$ [1]. The exact pressure and temperature at which hydrates form is however dependent on the composition of the gas and the ionic impurities in the water. At suitable conditions of pressure and temperature the water molecules arrange themselves to form cages, with each cage enclosing one gas molecule. Naturally occurring hydrates are found in a relatively narrow zone of ideal pressure and temperature that parallels and underlie: (a) the terrestrial surface in permafrost areas and (b) the seabed surface in deep-water oceanic sediments. The dominant hydrocarbon gas discovered in hydrate form is methane; as such, natural gas hydrates are increasingly viewed as a potential economic resource.

Globally, the distribution of natural gas hydrates has mainly been inferred from geophysical observations, the most widely used being the high-amplitude bottom-simulating reflector (BSR). This positive indicator was previously used to confirm the presence of gas hydrates in Block 27, offshore Trinidad [2]. In that study, it was also concluded that hydrate-bearing sediments may extend northward into the adjoining area of interest, Block 26 (Figure 1).

Table 1 is a summary of published values of acoustic properties in pure hydrates, water saturated sediments, hydrate-bearing sediments and gas bearing sediments [3]. As indicated, water saturated and gas bearing sediments have acoustic velocities in the order of $1.6-2.5$ and $0.16-1.45 \mathrm{~km} / \mathrm{s}$ respectively. The presence of hydrates in sediments however increases their average acoustic velocity to the order of $2.05-4.5 \mathrm{~km} / \mathrm{s}$.

Table 1. Summary of acoustic properties of hydrates [3].

\begin{tabular}{ccccc}
\hline Parameter & Water-Saturated & Hydrate-bearing & Pure hydrate & Gas-bearing \\
\hline $\begin{array}{c}\text { Compressional Wave } \\
\text { Vp }(\mathrm{km} / \mathrm{s})\end{array}$ & $1.6-2.5$ & $2.05-4.5$ & $3.25-3.6$ & $0.16-1.45$ \\
\hline
\end{tabular}

In the case of hydrate-bearing sediments, the high-amplitude BSR is the response of the seismic signal to the change from solid hydrate-bearing sediments to underlying sediments which may contain water and free gas. As a result, there is a decrease in the acoustic impedance as the seismic wave travels from the overlying high-acoustic velocity hydrate bearing zone, to the low acoustic velocity zone [1].

The depth of the BSR generally coincides with the base of the Gas Hydrate Stability Zone (GHSZ). This zone is defined by in-situ temperature and pressures, and its base is generally interpreted as representing the phase boundary between overlying gas hydrates and underlying free gas zone. As the base of the GHSZ is defined by pressure and temperature, the BSR generally runs parallel to the seafloor and cuts the dominant stratigraphy. The BSR is also generally recognized by its reversed polarity relative to the seafloor [1]. On occasion, bright reflectors have also been observed at the top of a hydrate-bearing layer [4]. 
Figure 1. Location map for blocks 26 and 27 offshore Trinidad.

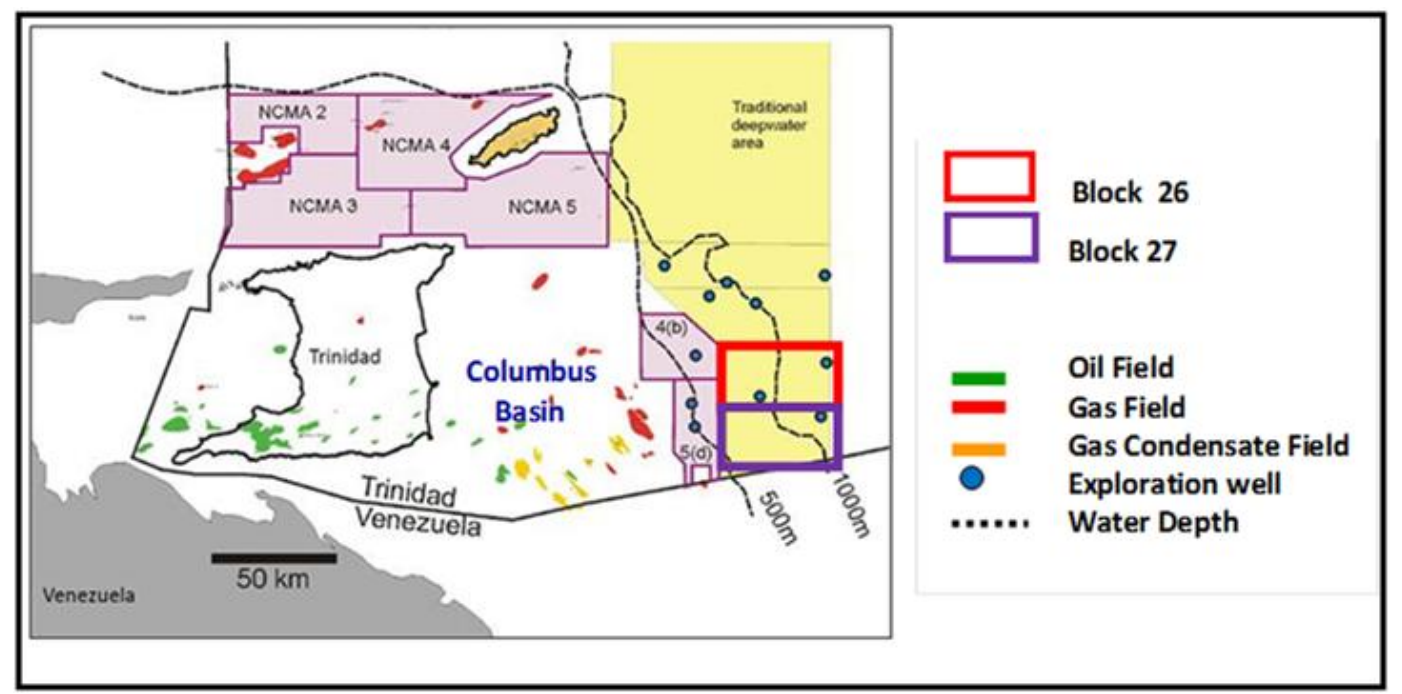

The Columbus Basin, located off the east coast of Trinidad in the Atlantic Continental Margin (Figure 1), is a sediment-rich depositional centre, formed as a result of the tectonic interaction of the Caribbean, South American and Atlantic Plates. The primary structural elements of the basin include: (1) transpressional northeast-southwest trending ridges and (2) northwest-southeast oriented, down to the northeast, normal faults.

The basin contains Cretaceous to recent sediments, where more than 12,200 $\mathrm{m}$ are Plio-Pleistocene sediments deposited by the Orinoco Delta system which now extends from Venezuela to southeast Trinidad [5,6]. It also contains several conventional oil and gas sandstone reservoirs trapped both in anticlinal ridges and against the northwest-southeast trending faults to produce structural closure. These conventional reservoirs can be found at depths from $1200 \mathrm{~m}$ to greater than $4000 \mathrm{~m}$, and exhibit high porosities (20 to $30 \%$ ) and permeabilities (10 to $1000 \mathrm{mD}$ ) [7,8]. In the study area, the conditions for hydrate formation are ideal where pressures are greater than 50 bars and temperatures are less than $10^{\circ} \mathrm{C}$.

Gas composition and isotope data indicate that both biogenic methane and thermogenic gas are present in the Columbus Basin [9]. The source of the biogenic gas is microbial methanogenesis that occurs as a result of the large influx of organic matter from the Orinoco Delta and at shallow depths [5]. Thermogenic gas comes from the breakdown of organic matter at depths great enough to prohibit bacterial action. This gas then migrates upwards through various pathways, such as faults and mud volcanoes.

In this study, three-dimensional (3D) seismic data for Block 26 were evaluated to determine if there are potential hydrate-bearing sediments. This forms part of a wider study aimed at characterizing potential hydrate deposits in the Atlantic Continental Margin offshore Trinidad and Tobago.

\section{Methodology}

Three-dimensional (3D) seismic data for Block 26 covered $1210 \mathrm{~km}^{2}$ of the slope environment in the Columbus Basin. The data were evaluated to determine if hydrate-bearing sediments are present, their areal extent and the depths to the base of these sediments. Using a geophysical interpretation workstation, the seafloor reflector was initially mapped to delineate the major structural landscape of 
the block. This reflector was taken as the first seismic reflector below the sea surface. The seismic volume beneath the seafloor was then examined for the occurrence of a BSR and this cross-cutting surface was mapped wherever evident. A Time Structure Map was produced to show the areal extent of the BSR. Check-shot data were available from one of the two exploration wells drilled in Block 26, and were used for depth conversion calculations from Two-Way Time (TWT). Subsea temperatures and water depths were also analysed to confirm that the oceanic sediments were at pressure and temperature conditions conducive to gas hydrate formation.

\section{Results and Discussion}

\subsection{Sea Floor Morphology}

The Time Structure Map of the seafloor reflector (Figure 2) indicated that the seafloor sloped gently to the north-east, which is in accordance with the known slope profile offshore the Columbus Basin. This was shown by an increase in TWT from approximately $900 \mathrm{~ms}$ in the west to $1800 \mathrm{~ms}$ on the eastern edge of the map. These TWT's corresponded to water depths of approximately 700 to $1400 \mathrm{~m}$ respectively.

A series of abrupt structural highs were also observed on seismic and are associated with deep-seated mud diapirs and mud volcanoes in the area [10-13]. Available data indicated that the gas phase of expelled fluids is essentially thermogenic methane, most likely generated below depths of $5000 \mathrm{~m}[10]$.

Figure 2. Time structure map of the sea floor in Block 26 off the east coast of Trinidad. The location of two exploration wells and mud volcanoes are shown. Two-way travel time and hence water depths increase to the east.

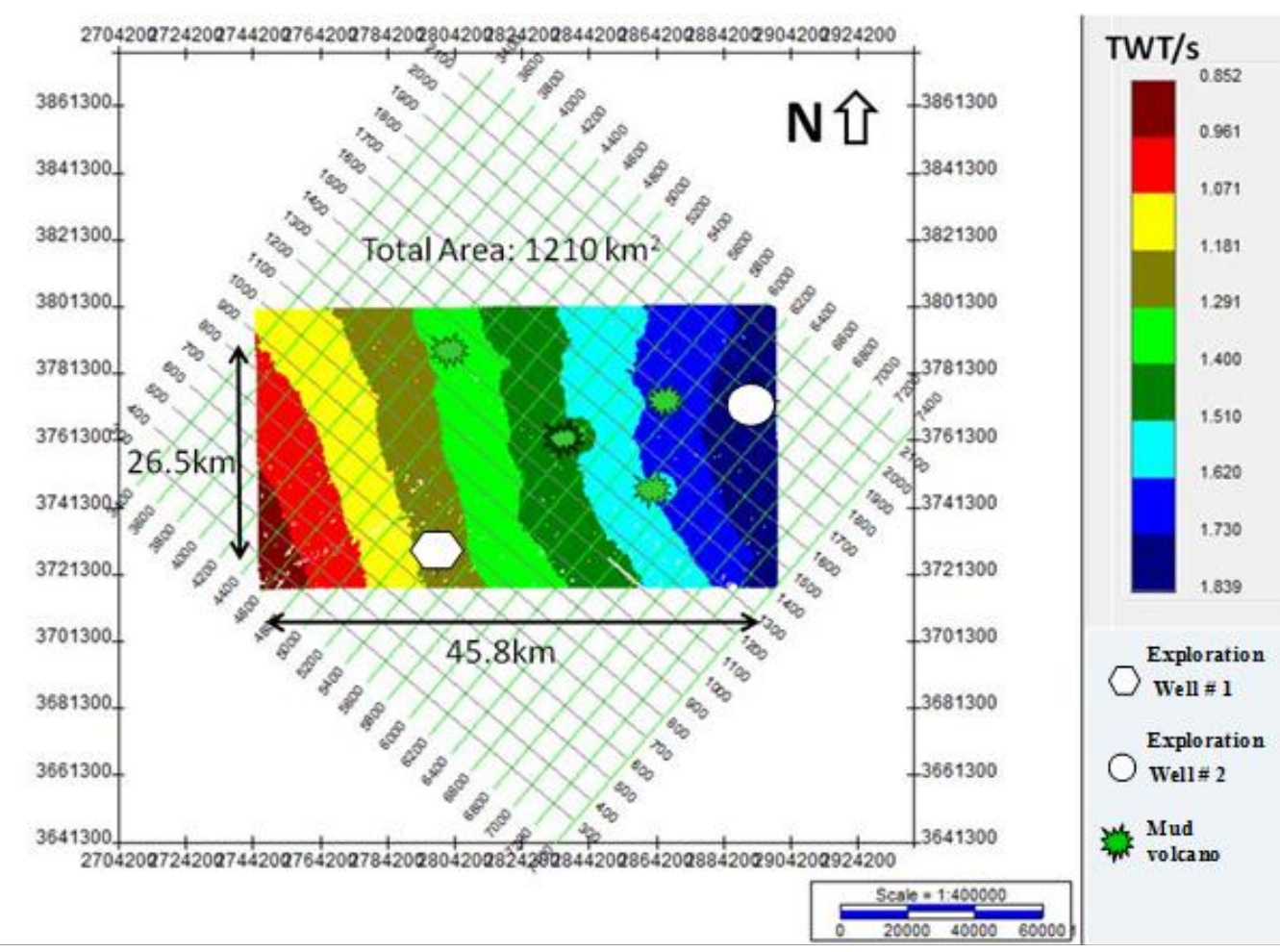




\subsection{Subsea Pressures and Temperatures}

The near seafloor temperature was determined to be $5{ }^{\circ} \mathrm{C}$ at a water depth of $921 \mathrm{~m}$ based on information from one exploration well within this block. Based on the water depth, and assuming a water gradient of $0.1 \mathrm{bar} / \mathrm{m}$, the pressure of the oceanic sediments in the vicinity of the exploration well is greater than 90 bars. These data indicated that the sediments exist at conditions which favour hydrate formation. Additionally, as the Columbus Basin is an organic rich depositional centre and a prolific hydrocarbon province, there is a high probability that the hydrocarbon gas needed for the formation of hydrates is present and in sufficient quantities.

\subsection{Gas Hydrate Indicator: Bottom-Simulating Reflector (BSR)}

The seismic section in Figure 3 shows the seafloor reflector (in yellow) at approximately $1800 \mathrm{~ms}$ and $1600 \mathrm{~ms}$ TWT in the southwest and northeast ends of the section respectively. An abrupt structural high was observed towards the centre of the section and was interpreted to be a mud volcano.

Figure 3. Seismic Profile along SW-NE Line 1. (A) Uninterpreted section highlighting the BSR and a mud diaper/volcano. To the southwest, the BSR cuts the dominant strata; (B) Interpreted section with location of BSR. The elevation of the BSR in the vicinity of the mud diapir is also highlighted; (C) The location of this seismic section in the Block 26 area.

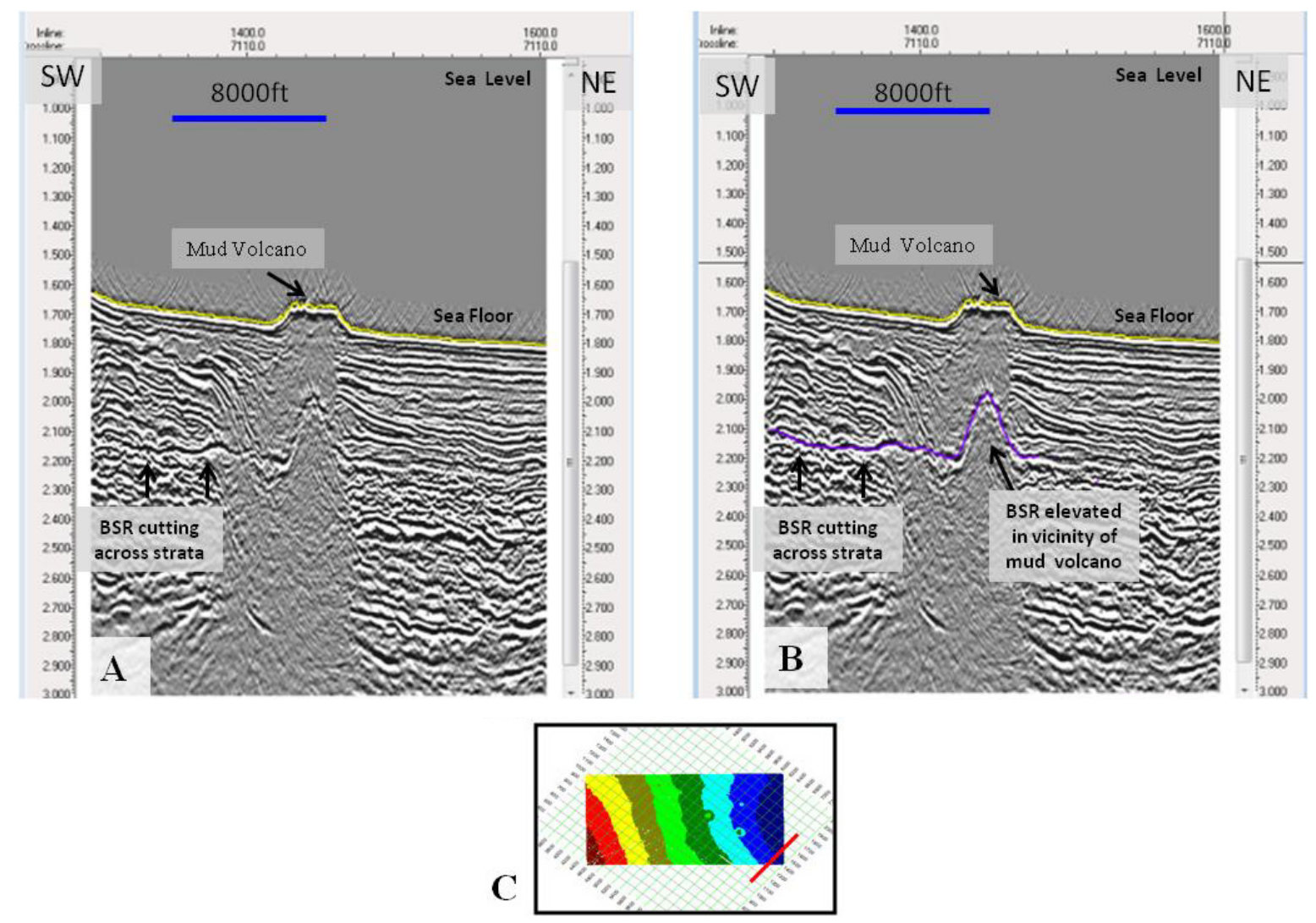

An anomalous cross-cutting feature (shown in blue) can also be observed running almost parallel to the seafloor in the southwest side of this section at approximately $2100 \mathrm{~ms}$ TWT. Notably, this feature 
becomes shallower in the vicinity of the mud volcano. The time of this event makes it unlikely to be a multiple, and by its amplitude and character is indicative of a BSR. The feature was consequently determined to be a BSR and indicate the presence of gas hydrates within Block 26.

In the vicinity of the mud volcano, the anomalous feature deviated upwards because the normal geothermal gradient was disturbed by upwelling mud. The temperature increase caused the BSR to migrate to a shallower depth. The rest of the BSR feature remained unaffected by the mud intrusion. Brooks et al. [14] also noted that a BSR which extends to the surface may be indicative of active venting at the seafloor.

In the seismic section in Figure 4, the seafloor can be observed at approximately $1300 \mathrm{~ms}$ to $1700 \mathrm{~ms}$ TWT from the northwest to the southeast of the section. A BSR is observed at approximately $1900 \mathrm{~ms}$ TWT in the middle of the section to $2100 \mathrm{~ms}$ southeast of the section, running almost parallel to the seafloor and cross-cutting the sloping strata.

Figure 4. Seismic Profile along NW-SE Line 2. (A) Uninterpreted section highlighting the BSR and a mud diaper/volcano. To the southeast, the BSR cuts the dominant strata; (B) Interpreted section with location of BSR; (C) The location of this seismic section in the Block 26 area.

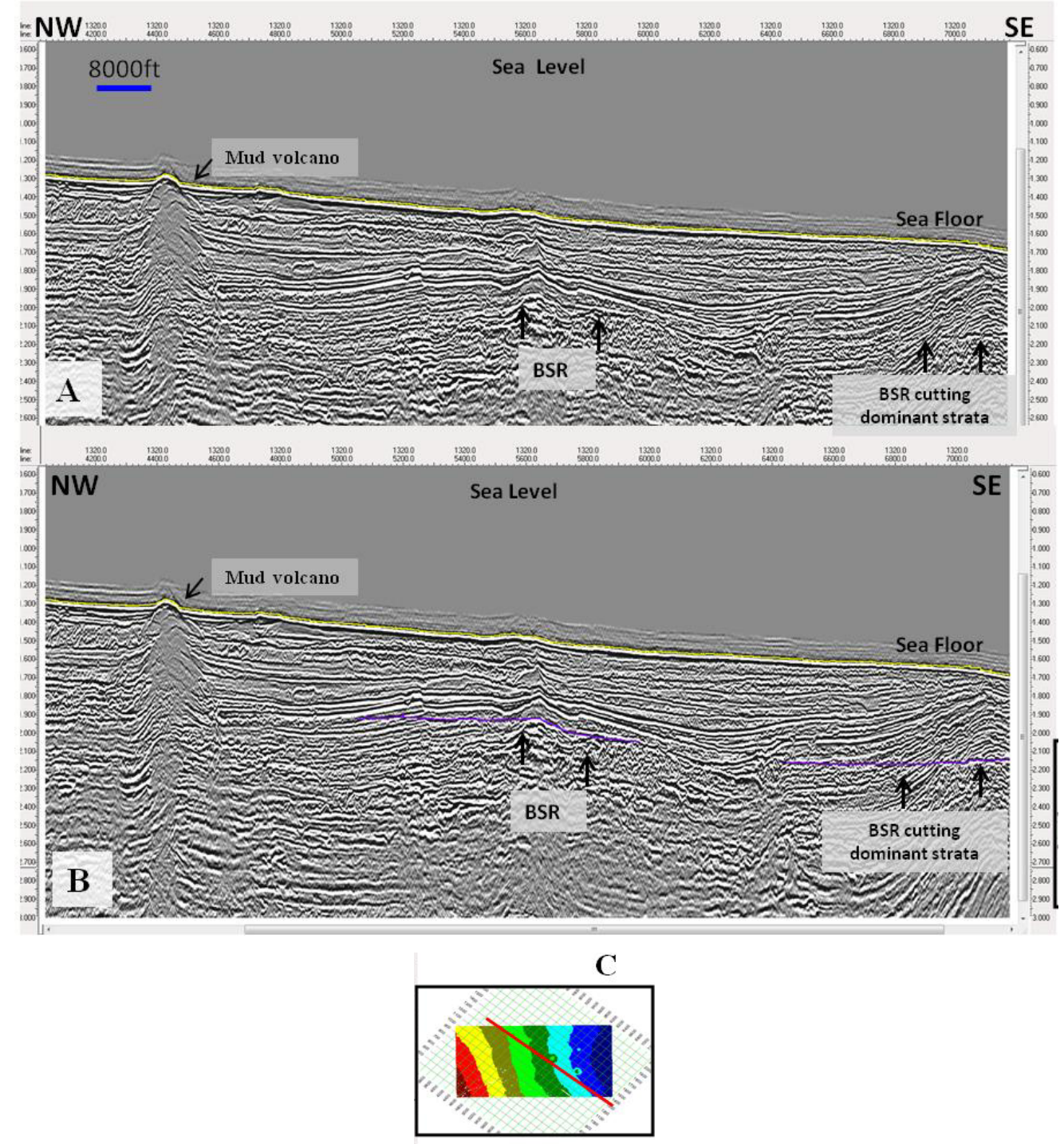


Figure 5 highlights the two areas where the BSR was easily identified in Block 26. The TWT of the observed BSR ranged between $1346 \mathrm{~ms}$ and $2520 \mathrm{~ms}$ on the western and eastern sides of the mapped area respectively. This increase in the TWT of the BSR towards the east of the block was expected, since water depths increase in an easterly direction, and the thickness of the GHSZ increases with water depth. The extent of the smaller area was approximately $13 \mathrm{~km}^{2}$, and the larger area, $507 \mathrm{~km}^{2}$. These areas total $520 \mathrm{~km}^{2}$ and represent approximately $43 \%$ of the study area, and generally coincide with the area in which the stratigraphy trended at an angle to the horizontal. In areas where the stratigraphy was generally parallel to the sea floor, the ability to detect the BSR, if present, was severely diminished. The absence of a BSR should therefore not be taken as indicative of the absence of hydrates in the sediments.

Figure 5. Contoured time structure map of BSR showing areas of occurrence.

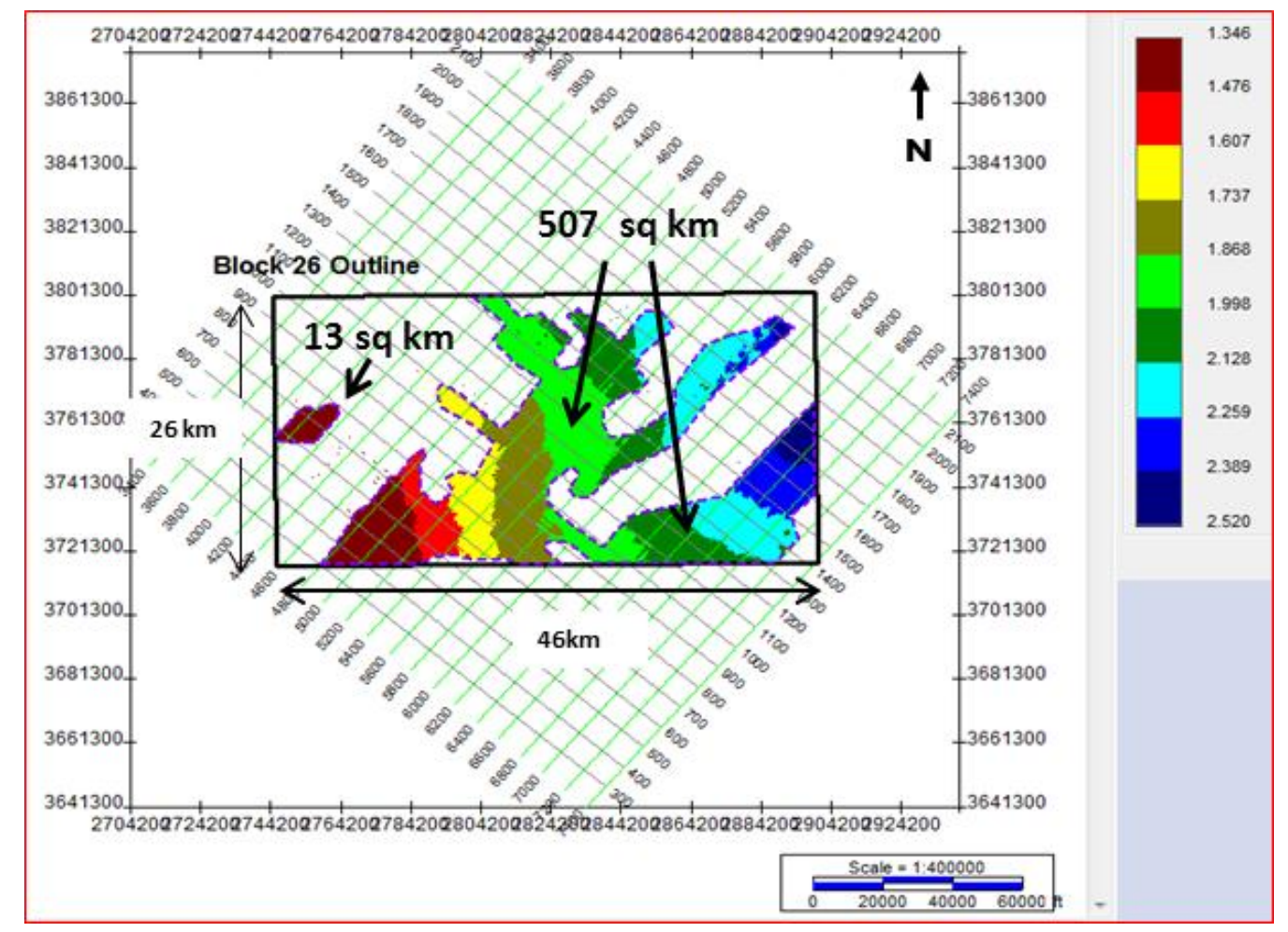

\subsection{Hydrate Stability Zone}

Check-shot data from one exploration well were used to determine the time-to-depth relationship for Block 26. The TWT of the mapped BSR, which ranged from approximately $1350 \mathrm{~ms}$ to $2500 \mathrm{~ms}$, equated to depths of approximately 1200 to $2400 \mathrm{~m}$. Based on the corresponding water depths of 800-1400 m, the thickness of the hydrate stability zone ranged from 400 to $1000 \mathrm{~m}$.

These thicknesses are considered to be within acceptable limits, as BSRs in oceanic sediments have been observed down to $1100 \mathrm{~m}$ beneath the sea floor [15]. Also, since gas hydrates are stable at higher temperatures as water depth/pressure increases, the TWT of the BSR also increases with water depth. As indicated earlier, one area where deviation from this trend occurs is in the vicinity of mud volcanoes, and these deviations have been seen in Block 26. 


\subsection{Discussion}

As a general guideline and to satisfy pressure and temperature requirements, hydrate bearing sediments can be found where the overlying sea-water depth is in excess of 200-500 m, with the actual depth dependent on the seafloor temperature and gas composition [16]. For example, while in the Barents Sea, BSRs have been observed on seismic lines in water depths of $345 \mathrm{~m}$ [17], in Japan in the Nankai Trough area, Japan, BSRs have been observed in water depth greater than $700 \mathrm{~m}$ [16]. In Blake Ridge, Oregon, BSRs have also been observed at water depths greater than $1000 \mathrm{~m}$ [16].

In Block 26, the water depths are greater than $600 \mathrm{~m}$ and the seafloor temperatures are less $10{ }^{\circ} \mathrm{C}$. As such the sediments close to the sea floor exist at conditions which favour hydrate formation. Figure 5 identifies the areas in the dataset where the BSR was easily identified and could be confidently mapped. Generally in those areas, there were dipping strata and the BSR could be easily identified cutting across the strata. The absence of the BSR in the other areas does not however mean that hydrates are not present. For example, in the Gulf of Mexico, hydrate bearing sediments have been identified in areas for which there was no widespread BSR $[18,19]$. This phenomenon has also been observed in the Mackenzie Delta, Canada [4] and is attributed to the absence of free gas at the base of the hydrate stability zone.

Identification of a BSR can also be difficult where the bedding is parallel to the seafloor. As an example of this, in Figure 6, an anomalous reflector is observed in the southwest of the section cutting across sloping strata. However towards the northeast of the section where the layering generally parallels the sea floor, it is difficult to discern the BSR. In addition, toward the middle of the section, and across the mud diapir, it was also difficult to discern the anomalous reflector.

Figure 5 indicates that a BSR was not observed in a significant portion of the western section of the mapped area. Figure 7, a time-slice through the seismic data at 2.2 seconds, identifies an area to the left of the mapped area where the seismic data were of poor quality. One notes that the area of poor data quality essentially overlaps the area where a BSR was not delineated.

The presence of gas necessary for hydrate formation may also vary laterally due to variations in trapping configuration, porosity and gas supply [20-22]. As such, BSRs may be laterally discontinuous. In the Columbus Basin, a known source of both thermogenic and biogenic gas which migrates along faults, fractures and permeable layers [5,9], hydrate-bearing sediments may therefore be localized. This will not give rise to a continuous BSR unless the gas is laterally distributed as could occur when reservoir properties are uniform. The phenomenon of the discontinuous BSR has been observed on the Gulf of Mexico [21] and in the Walker Ridge area [22]. In the case of the latter, the discontinuous BSR was associated with steeply dipping layers of varying lithology. 
Figure 6. Seismic Profile along SW-NE Line 3. (A) Uninterpreted section highlighting the BSR, mud diapir and horizontal layering. To the southwest, the BSR cuts the dominant strata; (B) Interpreted section with location of BSR; (C) The location of this seismic section in the Block 26 area.
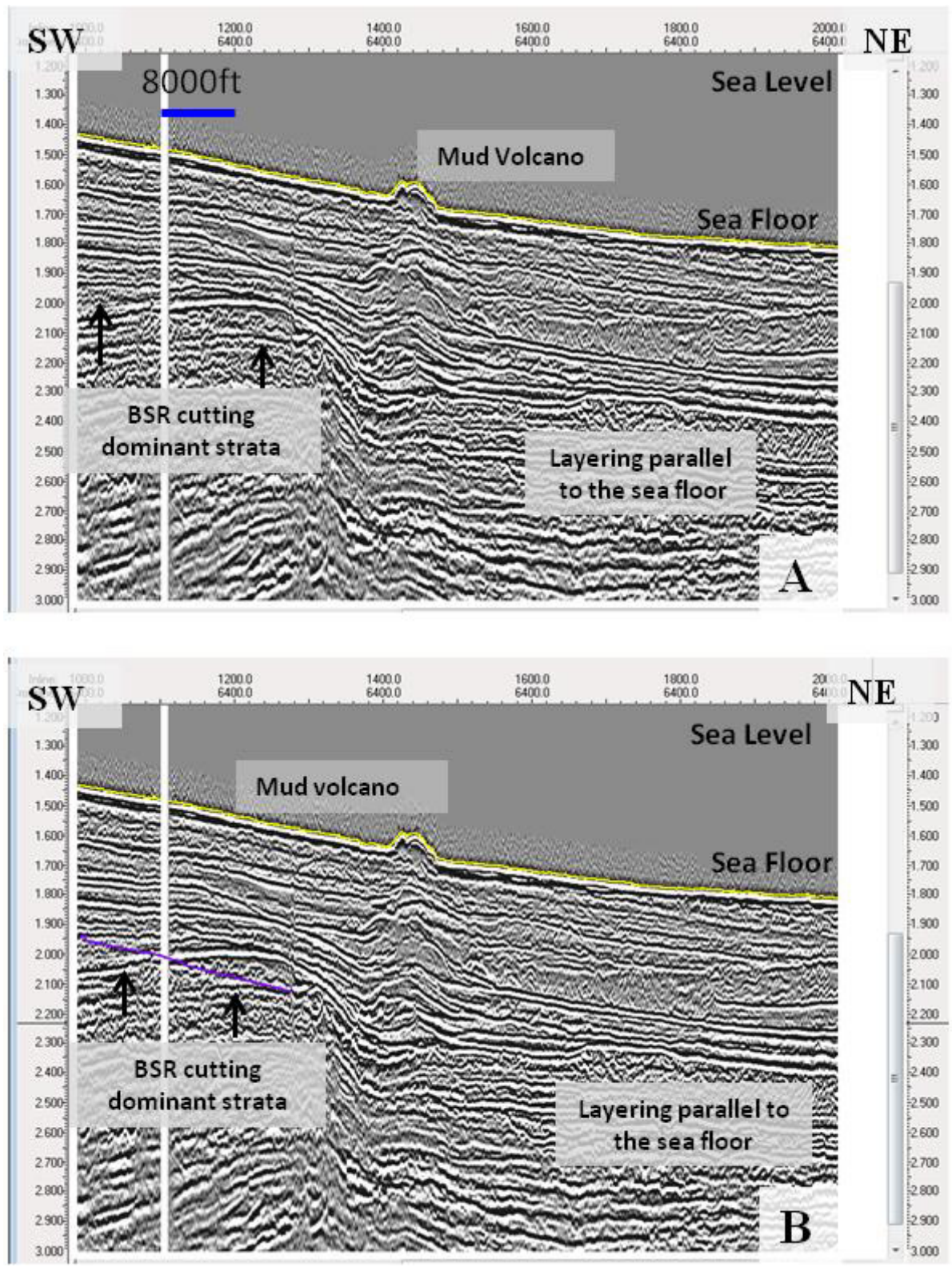

C

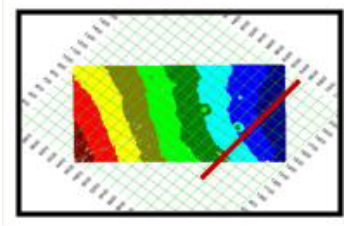


Figure 7. Time slice at $2.2 \mathrm{~s}$ highlighting areas with poor seismic data quality to the west, mud diapirs/volcanoes and the areal extent of the mapped BSR.

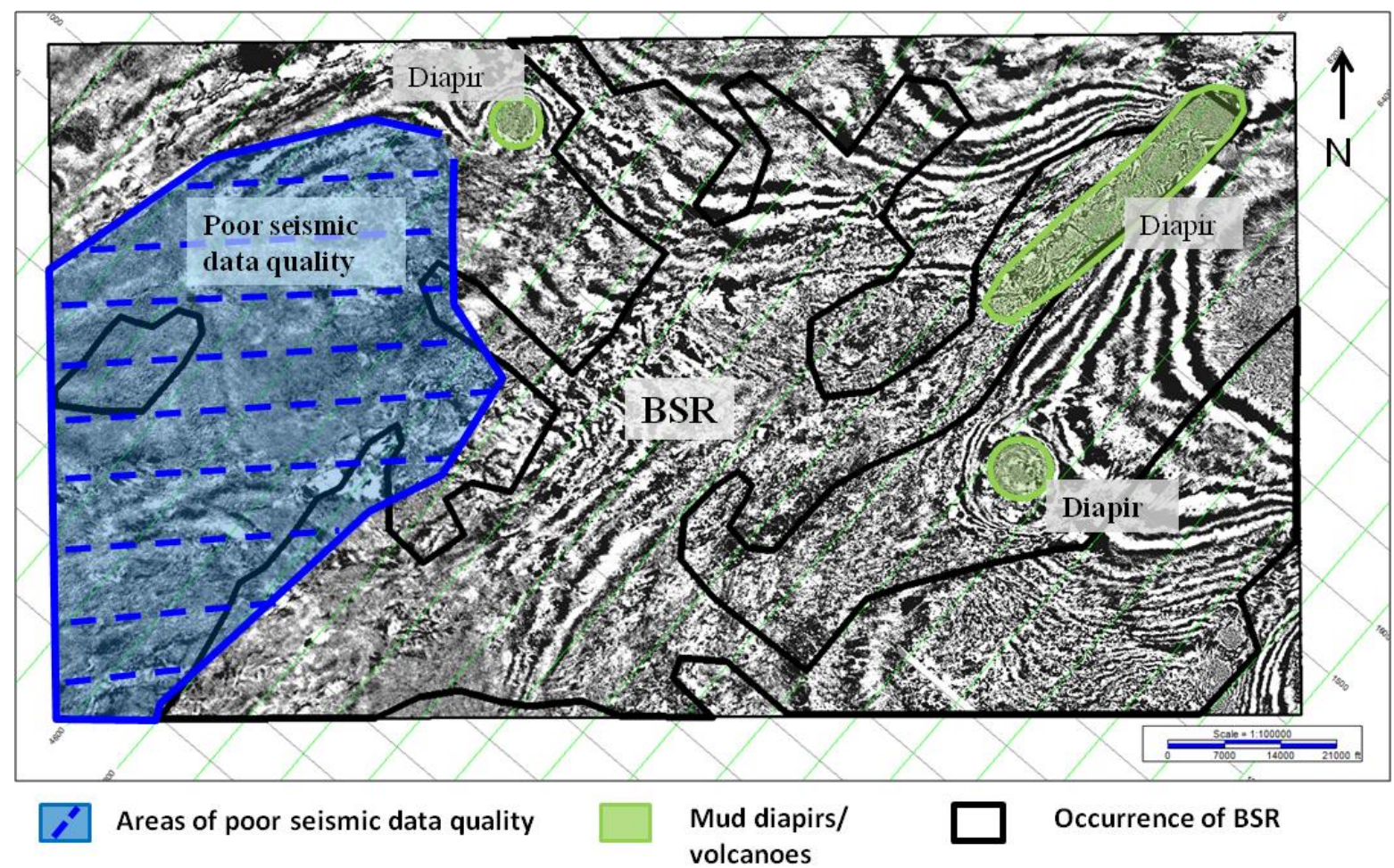

\section{Conclusions}

Subsea pressure and temperature data indicate that the sediments in Block 26 exist at conditions that favour hydrate formation. Also, given that the east coast of Trinidad is a sediment-rich depositional centre and a prolific hydrocarbon province, the probability is high that the hydrocarbon gas needed for the formation of hydrates is present and in sufficient quantities.

The south-eastern corner of Block 26 offshore Trinidad contains a seismic event that has been interpreted to be a BSR associated with the presence of gas hydrates. Where present, these BSR surfaces were observed to parallel the seafloor and cut across reflectors, except in the immediate vicinity of mud volcanoes where they generally migrate upwards.

The areal extent of the mapped BSR is approximately $520 \mathrm{~km}^{2}$ which accounts for approximately $43 \%$ of Block 26 , and appears to continue from that previously mapped in the southern Block 27 . The BSR observed in Block 26 also extends to the northern and eastern limits of the block, and suggests that hydrates may be present in the blocks immediately to the north and east of Block 26.

\section{Recommendations}

Although exploration wells have been drilled in Block 26, the intervals immediately beneath the seafloor were not logged or cored. It is recommended that future wells drilled off the East coast of Trinidad be logged and cored across the shallow horizons to obtain data for detailed characterization of potential hydrate-bearing zones. Also, since gas composition significantly impacts the conditions under which gas hydrates are stable, the theoretical depth to the base of the hydrate stability zone and the 
thickness of the interval, site-specific gas samples should be taken and analysed to allow for determination of hydrate pressure-temperature relationships specifically for Trinidad's deepwater blocks.

\section{Acknowledgments}

The authors are thankful to the Ministry of Energy and Energy Affairs for use of the seismic dataset, the University of the West Indies for funding this study, and David Borde and the staff of PetroCom Technologies Limited for their technical assistance.

\section{References}

1. Kvenvolden, K.A. A Primer on the Geological Occurrence of Gas Hydrate. In Gas Hydrates: Relevance to the World Margin Stability and Climate Change, Special Publications; Henriet, J.P., Mienert, J., Eds.; Geological Society: London, UK, 1998; pp. 9-30.

2. Figueira, B.M.; DeLandro-Clarke, W.; Bertrand, W.; Marcelle-De Silva, J. Delineation of Natural Gas Hydrates-Block 27 Offshore Trinidad. Trinidad and Tobago; Unpublished Report to the Ministry of Energy and Energy Industries (MOEEI): Port of Spain, Trinidad and Tobago, 2009.

3. Anderson, A.L. Remote Acoustic Characterization of the Seafloor Including Gassy and Hydrated Sediment Regions. In Proceedings of the 2nd International Offshore and Polar Engineering Conference, Golden, CO, USA, 1992; pp. 674-683.

4. Bellefleur, G.; Riedel, M.; Brent, T. Seismic characterization and continuity analysis of gas-hydrate horizons near Mallik research wells, Mackenzie Delta, Canada. Lead. Edge 2006, 25, 599-604.

5. Wood, L.J. Chronostratigraphy and tectonostratigraphy of the columbus basin, eastern offshore Trinidad. AAPG Bull. 2000, 84, 1905-1928.

6. Brami, T.R.; Pirmez, C.; Archie, L.S.; Heerala, S.; Holman, K.L. Late Pleistocene Deep-Water Stratigraphy and Depositional Processes. In Proceedings of the GCSSEPM Foundation 20th Annual Research Conference Deep-Water Reservoirs of the World, Houston, TX, USA, December 2000; pp. 104-115.

7. Lumsden, P.J.; Balgobin, C.J.; Bodnar, D.; Brayshaw, A.C.; Dyer, B.L.; Gainski, M.; Hennington, E.R.; Burch, T.K.; Farmer, C.L.; Saldana, M.A. The Kapok Field-A Step Change for Trinidad Gas Developments. In Proceedings of the SPE Gas Technology Symposium (SPE75670), Calgary, Canada, April 2002; pp. 1-10.

8. Jemmott, S. Reservoir Surveillance in Gas Reservoirs Offshore Trinidad. In Proceedings of the Society of Petroleum Engineers Latin American and Caribbean Petroleum Engineering Conference (SPE94820), Rio de Janeiro, Brazil, June 2005; pp.1-9.

9. Gibson, R.G.; Dzou, L.I.P.; Greeley, D.F. shelf petroleum system of the Columbus basin, offshore Trinidad, West Indies. Source rock, thermal history, and controls on product distribution. Marine Pet. Geol. 2004, 21, 97-108.

10. Deville, E.; Battani, A.; Griboulard, R.; Guerlais, S.; Herbin, J.P.; Houzay, J.P., Muller, C.; Prinzhofer, A. The Origin and Processes of Mud Volcanism: New Insights from Trinidad. Geological Society: London, UK, 2003; Volume 216, pp. 475-490. 
11. Deville, E.; Guerlais, S.-H.; Callec, Y.; Griboulard, R.; Huyghe, P.; Lallemant, S.; Mascle, A.; Noble, M.; Schmitz, J. The Collaboration of the CARAMBA Working Group. Liquefied vs. stratified sediment mobilization processes: Insight from the South of the Barbados accretionary prism. Tectonophysics 2006, 428, 33-47.

12. Deville, É.; Guerlais, S.-H.; Lallemant, S.; Schneider. F. fluid dynamics and subsurface sediment mobilization processes: an overview from the Southeastern Caribbean. Basin Res. 2010, 22, 361379.

13. De Landro Clarke, W. Geophysical Aspects of Shale Mobilization in the Deep Water off the East Coast of Trinidad. In Shale Tectonics; Wood, L., Ed.; American Association of Petroleum Geologists: Tulsa, OK, USA, 2010; Volume 93, pp. 111-118.

14. Brooks, J.M.; Bernard, B.B.; Summer, N.S.; Sullivan, S. Gas Hydrates in Seabed Sediments Offshore Trinidad/Barbados. In Proceedings of the AAPG Annual Meeting, Dallas, TX, USA, April 2004; pp. 18-21.

15. Hyndman, R.D.; Davis, E.E. A Mechanism for the formation of methane hydrate and seafloor bottom-simulating reflectors by vertical fluid Expulsion. J. Geophys. Res. 1992, 97, 7025-7041.

16. Milkov, A.V.; Sassen, R. Economic geology of offshore gas hydrate accumulations and provinces. Marine Pet. Geol. 2002, 19, 1-11.

17. Mienert, J.; Posewang, J.; Baumann, M. Gas Hydrates Along the northeastern Atlantic Margin: Possible Hydrate-Bound Margin Instabilities and Possible Release of Methane. In Gas Hydrates: Relevance to the World Margin Stability and Climate Change, Special Publications; Henriet, J.P., Mienert, J., Eds.; Geological Society: London, UK, 1998; Special Edition No. 137, pp. 275-291.

18. Dai, J.; Xu, H.; Snyder, F.; Dutta, N. Detection and estimation of gas hydrates using rock physics and seismic inversion: examples from the northern deepwater Gulf of Mexico. Lead. Edge 2004, 60-66.

19. Hardage, B.A.; Roberts, H.H. Gas hydrate in the Gulf of Mexico: What and where is the seismic target? Lead. Edge 2006, 25, 566-571.

20. Clennell, M.B.; Judd, A.; Hovland, M. Movement and Accumulation of Methane in Marine Sediments: Relation to Gas Hydrate Systems. In Natural Gas Hydrate in Oceanic and Permafrost Environments, Coastal Systems and Continental Margins; Max, M.D., Ed.; Kluwer: Dordrecht, The Netherlands, 2000; pp. 61-76.

21. Kou, W.W.H., Smith, M.A., Ahmed, A.; Kuzela, R. Direct seismic indicators of gas hydrates in the Walker Ridge and Green Canyon areas, deepwater Gulf of Mexico. Lead. Edge 2007, 26, 152-155.

22. Birchwood, R.; Dai, J.; Shelander, D.; Boswell, R.; Collett, T.; Cook, A.; Dallimore, S.; Fujii, K.; Fukuhara, M.; Kusaka, K.; Murray, D.; Saeki, T. Developments in gas hydrates. Oilfield Rev. 2010, 22, 18-33.

(C) 2012 by the authors; licensee MDPI, Basel, Switzerland. This article is an open access article distributed under the terms and conditions of the Creative Commons Attribution license (http://creativecommons.org/licenses/by/3.0/). 